\title{
KEEFEKTIVAN STRATEGI BRAINSTORMING DALAM PEMBELAJARAN MENULIS PARAGRAF ARGUMENTASI SISWA KELAS XI SMA NEGERI 1 BONTONOMPO KABUPATEN GOWA
}

\author{
Munirah \\ Pendidikan Bahasa dan Sastra Indonesia, Universitas Muhammadiyah Makassar \\ munirah@unismuh.ac.id
}

\begin{abstract}
Essay writing skills will not happen by it self, but requires continuous coaching and training, continuous, and performed as a process of development. For the purpose of writing essay was achieved with good arguments, then teaching essay writing arguments should be sought to be gradual and planned. This study aims to determine the effectiveness of brainstorming strategies in teaching students to write a paragraph argumentation class XI SMA Negeri 1 Bontonompo Gowa. The study design used a quasi-experimental nature. The study population was the overall Class XI student of SMAN 1 Bontonompo Gowa. The study sample consisted of two classes, namely VIIIA grade students as an experimental class and grade students VIIIB as the control class. The technique used in this study is a written test, while the technique of data analysis using statistical techniques of descriptive and inferential statistics. Results of the ability to write a paragraph argumentation by applying the experimental class brainstorming strategy shows the average value of students after having a treatment reached 78.87, while in the control group after treatment or action held by applying conventional learning in writing paragraph Argumentsi only reached 73.80. The results ofinferential analysis using the $t$ test calculations, it appears thatthe application of effective brainstorming strategies applied in teachingessay writing paragraphs argument GradeXI SMAN 1Bontonompo Gowa. It was based on the resultst count $_{\text {of }}$ 2,187 compared with 2,002 $t_{\text {table }}$ with a significant level of0.033. This means $\mathrm{H}_{\mathrm{o}}$ rejected and $\mathrm{H}_{1}$ accepted. In accordance with the results of the research, it can be concluded that effectivebrainstorming strategies applied in teaching writing paragraphs argument Grade XISMAN 1 Bontonompo Gowa.
\end{abstract}

Keywords : Brainstorming Strategies, and Writing Argument Paragraph

\begin{abstract}
Abstrak
Kemampuan menulis karangan tidak akan terjadi dengan sendirinya, tetapi memerlukan pembinaan dan latihan terus menerus, berkesinambungan, dan dilakukan sebagai proses pengembangan. Agar tujuan menulis karangan argumentasi itu tercapai dengan baik, maka pengajaran menulis karangan argumentasi harus diupayakan untuk dilakukan secara bertahap dan berencana.

Penelitian ini bertujuan untuk mengetahuikeefektivan strategibrainstorming dalam pembelajaran menulis paragrafargumentasi siswakelas XI SMA Negeri 1Bontonompo Kabupaten Gowa.Desain penelitian yang digunakan bersifat eksperimen semu. Populasi penelitian ini adalah keseluruhan Siswa Kelas XI SMA Negeri 1Bontonompo Kabupaten Gowa. Sampel penelitian ini terdiri atas dua kelas, yaitu siswa kelas $\mathrm{VIII}_{\mathrm{A}}$ sebagai kelas eksperimen dan siswa kelas $\mathrm{VIII}_{\mathrm{B}}$ sebagai kelas kontrol. Teknik
\end{abstract}


yang digunakan dalam penelitian ini adalah tes tertulis, sedangkan teknik analisis data menggunakan teknik statistik deskriptif dan statistik inferensial.

Hasil kemampuan menulis paragraf argumentasidengan menerapkan strategi brainstormingpada kelas eksperimen menunjukkan nilai rata-rata siswa setelah diadakan perlakuan mencapai 78,87, sedangkan pada kelas kontrol setelah diadakan perlakukan atau tindakan dengan menerapkan pembelajaran konvensional dalam menulis Paragraf Argumentsi hanya mencapai 73,80.

Hasil analisis inferensial dengan menggunakan perhitungan uji t, tampak bahwa penerapan strategi brainstormingefektif diterapkan dalam pembelajaran menulis karangan ParagrafArgumentasi Siswa Kelas XI SMA Negeri 1Bontonompo Kabupaten Gowa. Hal ini berdasarkan hasil $t_{\text {hitung }}$ sebesar 2,187 dibandingkan dengan $t_{\text {tabel }}$ sebesar 2,002 dengan taraf signifikan 0,033 . Hal ini berarti $\mathrm{H}_{0}$ ditolak dan $\mathrm{H}_{1}$ diterima. Sesuai dengan hasil penelitian, dapat disimpulkan bahwa strategi brainstormingefektif diterapkan dalam pembelajaran menulis ParagrafArgumentasi Siswa Kelas XI SMA Negeri 1Bontonompo Kabupaten Gowa

\section{Kata Kunci :Strategi Brainstorming, dan Menulis Paragraf Argumentasi}

\section{Pendahuluan}

Pembelajaran bahasa

Indonesia secara fungsional adalah pembelajaran yang lebih menekankan siswa untuk belajar berbahasa, dalam kaitannya dengan fungsi bahasa sebagai alat untuk berkomunikasi. Dalam mata pelajaran Bahasa Indonesia, menulis adalah salah satu keterampilan berbahasa yang diajarkan. Menulis merupakan salah satu keterampilan berbahasa yang digunakan untuk berkomunikasi secara tidak langsung atau tidak bertatap muka dengan orang lain. Menulis juga salah satu kegiatan yang produktif dan ekspresif.

Keterampilan menulis memegang peranan penting dalam kehidupan sehari-hari. Oleh karena itu, sering digunakan dalam menyatakan gagasan atau pikirannya dengan tulisan atau karangan. Keterampilan menulis berkembang melalui latihan. Adanya kemampuan menuangkan gagasan diawali dengan munculnya suatu kegemaran dalam diri seseorang sehingga menumbuhkan keinginan untuk melatih diri dalam menuliskan gagasan yang ada dalam pemikiran individu. Keterampilan menulis sering dikatakan keterampilan yang paling kompleks dan bersifat ekspresif, misalnya pada sebuah karangan terutama paragraf argumentasi. Menulis paragraf argumentasiharus menggunakan kata-kata yang saling berhubungan, penyusunan kalimat yang satu tidak terlepas dengan kalimat yang lainnya, sehingga membentuk suatu paragraf yang utuh, paragraf demi paragraf tersusun dengan benar sehingga membentuk karangan yang baik dan tidak menimbulkan keraguan makna.

Untuk menulis suatu paragraf argumentasi diperlukan ide (gagasan). Tidak ada satu paragraf argumentasi tanpa adanya gagasan. Gagasan adalah esensi dari nilai-nilai yang hendak ditawarkan penulis kepada pembaca. Makin rajin seseorang menulis, makin mudah mendapatkan ide untuk karyakaryanya. Agar sumber ide tidak kunjung habis, penulis juga perlu menimba ide-ide dari literatur yang luas.

Menurut Hernowo (2004: 169), gagasan hebat itu datang bagaikan kilat. Gagasan yang bagus 
kadang datang tidak terduga. Gagasan itu bisa muncul di saat kapan pun dan dimana pun. Sepertinya, seorang penulis tidak hanya menunggu lantas memperoleh gagasan hebat begitu saja. Perlu ada pengondisian tertentu atau senantiasa menyiapkan diri dalam menangkap gagasan hebat dan kemudian memunculkannya.

Menulis gagasan dalam bentuk paragraf argumentasi merupakan kompetensi dasar yang terdapat dalam Kurikulum Tingkat Satuan Pendidikan (KTSP). Penuangan gagasan tidak terjadi begitu saja tanpa suatu proses dan latihan dalam mengungkapkan ide yang ada dalam pikiran siswa. Keterampilan dalam menulis gagasan sering kali terhambat oleh kurang tepatnya strategi yang digunakan guru dalam proses belajar mengajar sehingga berdampak pada kurangnya motivasi, minat, dan pembiasaan siswa untuk menuliskan gagasannya.

$$
\text { Berdasarkan }
$$

studi

pendahuluan peneliti, dengan melakukan observasimenunjukkan bahwa kondisi realitas yang terjadi di SMA Negeri 1 Bontonompo yangdiungkapkan oleh salah seorang guru bahasa Indonesia khususnya dalam pembelajaran menulis, guru masih menggunakan metode atau strategi yang lazim digunakan adalah metode diskusi kelompok, partisipatori, ceramah, dan lain-lain. Metode ini hanya mampu mengaktifkan 2-3 orang siswa yang pada dasarnya siswa tersebut dari awal memang memiliki kemampuan dan kepercayaan diri dalam mengungkapkan ide atau gagasannya di depan kelas. Hal inilah yang mendorong peneliti untuk memulai tahap penuangan gagasan dalam bentuk tulisan agar siswa terbiasa dan terlatih dalam mengungkapkan gagasan, khususnya dalam bentuk paragraf argumentasi.

Bedasarkan pada uraian di atas sebagai alternatif pemecahan masalah dalam pembelajaran menulis paragraf argumentasi, peneliti menerapkan penggunaan strategi pembelajaran

brainstorming.Brainstorming

merupakan kegiatan berpikir berdasarkan asosiasi yang bebas dalam menemukan hal-hal apa saja yang berkaitan dengan perihal pokok karangan. Kegunaan brainstorming gagasan agar siswa dapat melakukan penulisan dengan mudah dan lebih terbantu dalam proses penulisan selanjutnya.

Strategi brainstorming adalah suatu bentuk diskusi dalam rangka menghimpun gagasan, pendapat, informasi, pengetahuan, pengalaman, dari semua peserta. Berbeda dengan diskusi, dimana gagasan dari seseorang dapat ditanggapi (didukung, dilengkapi, dikurangi, atau tidak disepakati) oleh peserta lain, pada penggunaan strategi curah pendapat pendapat orang lain tidak untuk ditanggapi. Tujuan curah pendapat adalah untuk membuat kompilasi (kumpulan) pendapat, informasi, pengalaman semua peserta yang sama atau berbeda. Hasilnya kemudian dijadikan peta informasi, peta pengalaman, atau peta gagasan untuk menjadi pembelajaran bersama (Madusari: 2009).

Berdasarkan uraian yang dikemukakan di atas, peneliti tertarik untuk melakukan penelitian dalam pembelajaran menulis paragraf argumentasi. Dalam hal ini, peneliti melakukan penelitian eksperimen semu dengan judul "Keefektivan strategi brainstorming dalam Pembelajaran Menulis Paragraf 
Argumentasi pada Siswa Kelas XI SMA Negeri 1 Bontonompo Kabupaten Gowa.

\section{Kajian Pustaka}

\section{A. Pengertian Menulis}

Menulis merupakan salah satu kegiatan berbahasa yang produktif, yaitu keterampilan seseorang untuk mengungkapkan atau mengekspresikan ide atau perasaan kepada orang lain melalui bahasa tulisan. Menulis adalah sebuah kegiatan merekam suatu ide, gagasan, dan pikiran untuk dikomunikasikan kepada orang lain (pembaca) melalui kode-kode huruf yang telah disepakati secara konvensional".

$$
\text { Tarigan(1999 }
$$

mengungkapkan menulis adalah menirukan atau melukiskan lambanglambang grafik yang menggambarkan suatu bahasa yang dipahami seseorang, sehingga orang lain dapat membaca lambang-lambang grafik tersebut.

Dalam Kamus Besar Bahasa Indonesia cetakan ke-3, tertulis bahwa makna kata menulis adalah melahirkan pikiran atau perasaan (seperti mengarang, membuat surat) dengan tulisan. Sesuatu yang lahir dari pikiran dan perasaan berbentuk gagasan. Menyampaikan gagasan melalui tulisan sangat berbeda dengan menyampaikan gagasan melalui lisan. Gagasan yang dikeluarkan melalui tulisan harus lebih tertata dan tertib daripada gagasan yang keluar melalui pembicaraan.

Berdasakan uraian tersebut, maka dapat disimpulkan bahwa menulis merupakan sebuah kegiatan penuangan ide, informasi, perasaan, maupun khayalan ke dalam lambanglambang grafik yang terstruktur dan teratur.

\section{B. Pengertian Paragraf Argumentasi}

Paragraf argumentasi adalah suatu bentuk retorika yang berusaha untuk mempengaruhi sikap dan pendapat orang lain, agar mereka itu percaya dan akhirnya bertindak sesuai dengan apa yang diinginkan penulis atau pembicara (Keraf, 2007:3).

Argumentasi adalah karangan yang berusaha memberikan alasan untuk memperkuat atau menolak suatu pendapat, pendirian, atau gagasan. Jadi, karangan argumentasi memuat argumen, yaitu bukti dan alasan yang dapat meyakinkan orang bahwa pendapat tersebut memang benar (Nursisto dalam Zainal, 2007: 43).

Menurut Suparni (dalam Ismayani, 2007: 18) bahwa argumentasi adalah jenis karangan yang tujuannya memengaruhi penulis. Dalam urutannya penulis mengembangkan alasan-alasan yang kuat dan bukti-bukti yang meyakinkan sehingga pembaca membenarkan gagasan atau ide-ide penulis.

Dari beberapa uraian di atas, dapat disimpulkan bahwa efektivitas pembelajaran menulis paragraf argumentasi adalah suatu program pembelajaran dengan pencapaian tujuan pembelajaran yang dinyatakan dengan hasil yang dicapai yang berfungsi secara keseluruhan bagi siswa dalam mengembangkan satu ide pokok pikiran yang dapat memperkuat atau menolak suatu pendapat yang disertai dengan alasanalasan dan bukti untuk memperkuat pendapat dengan tujuan untuk meyakinkan pembaca.

\section{Ciri-ciri Paragraf Argumentasi} Menurut Junus (dalam Rini, 2006: 11), ciri-ciri karangan argumentasi antara lain: 
a) Sasaran utamanya adalah memengaruhi dan mengubah sikap dan opini orang lain.

b) Merupakan tulang punggung karya ilmiah.

c) Berusaha menghindari aspek emosi.

d) Menunjukkan kelemahan dan kesalahan orang lain.

e) Menunjukkan bukti-bukti.

f) Kritis dan logis.

2. Dasar Penyusunan Paragraf Argumentasi

Menurut Keraf (2007), dasar yang harus diperhatikan sebagai titik tolak argumentasi adalah:

a) Pembicara atau pengarang harus mengetahui serba sedikit tentang subyek yang akan dikemukakannya, sekurangkurangnya mengenai prinsipprinsip ilmiahnya. Karena argumentasi pertama-tama didasarkan pada fakta, informasi, evidensi, dan jalan pikiran yang menghubung-hubungkan faktafakta dan informasi-informasi tersebut. Dengan mengetahui serba sedikit mengenai obyek yang akan dikemukakannya, serta mengetahui prinsip ilmiah yang dikemukakannya tadi, maka penulis atau pembicara dapat memperdalam masalah tersebut dengan penelitian, observasi, dan autoritas untuk memperkuat data dan informasi yang telah diperolehnya.

b) Pengarang harus bersedia mempertimbangkan pandanganpandangan atau pendapat-pendapat yang bertentangan dengan pendapatnya sendiri. Mempertimbangkan pendapat lawan tidak berarti harus menyerah kepada lawan. Mempertimbangkan pendapat lawan adalah dengan tujuan untuk mengetahui apakah di antara fakta-fakta yang diajukan lawan ada yang dapat dipergunakannya, sehingga malah akan memperlemah pendapat lawan tadi. Oleh karena itu dapat juga terjadi bahwa fakta dan evidensi lawanlah yang benar, sehingga pendapat lawanlah yang harus diterima.

c) Pembicara atau penulis argumentasi harus berusaha untuk mengemukakan pokok persoalannya dengan jelas; ia harus menjelaskan mengapa ia harus memilih topik tersebut. Sementara itu ia pula harus mengemukakan konsep-konsep dan istilah-istilah yang tepat.

d) Pembicara atau penulis harus menyelidiki persyaratan mana yang masih diperlukan bagi tujuantujuan lain yang tercakup dalam persoalan yang dibahas itu, dan sampai mana kebenaran dari persyaratan yang telah dirumuskannya itu.

e) Dari semua maksud dan tujuan yang terkandung dalam persoalan itu, maksud yang mana yang lebih memuaskan pembicara atau penulis untuk menyampaikan masalahnya.

\section{Strategi Brainstorming}

Kajian strategi brainstorming dijabarkan sebagai berikut: 1) pengertian strategi brainstorming; 2) ruang lingkup strategi brainstorming; 3) prinsip strategi brainstorming; 4) keuntungan dan kelemahan penggunaan strategi brainstorming; 5) langkah-langkah dalam penerapan strategi brainstorming.

\section{Pengertian \\ Strategi Brainstorming} Strategi brainstorming adalah suatu bentuk diskusi dalam rangka menghimpun gagasan, pendapat, informasi, pengetahuan, 
pengalaman, dari semua peserta. Berbeda dengan diskusi, dimana gagasan dari seseorang dapat ditanggapi (didukung, dilengkapi, dikurangi, atau tidak disepakati) oleh peserta lain, pada penggunaan strategi curah pendapat pendapat orang lain tidak untuk ditanggapi. Tujuan curah pendapat adalah untuk membuat kompilasi (kumpulan) pendapat, informasi, pengalaman semua peserta yang sama atau berbeda. Hasilnya kemudian dijadikan peta informasi, peta pengalaman, atau peta gagasan untuk menjadi pembelajaran bersama (Madusari: 2009).

\section{Ruang Lingkup Brainstorming} Brainstorming memiliki ruang lingkup seperti yang dikemukakan oleh Boldman (dalam Marina, 2005: 31) yaitu:

1) Memilih Topik

Dalam hal ini, siswa diberikan kesempatan untuk memilih topik yang mereka ingin tulis secara bebas.

2) Menulis Beberapa Kemungkinan Ide yang Berhubungan dengan Topik Tersebut

Tahap ini, siswa diharapkan dapat menuliskan beberapa ide atau gagasannya dari topik yang telah dipilih dalam bentuk pernyataan berupa kata, frasa, atau sebagai informasi.

3) Mengualifisikan Ide

Dalam mengualifikasikan ide, saat itu pula siswa diberikan kesempatan menuliskan apa pun yang berkaitan dengan ide yang dipilihnya. Ide-ide yang tidak sesuai dengan topik dikeluarkan dan menyusun ide yang berkaitan dengan urutan yang jelas. Urutan ide-ide ini membantu siswa dalam memulai atau menuliskan gagasannya.

Brainstorming dapat dilakukan secara berkelompok atau secara individual. Apabila dikerjakan secara berkelompok, seseorang harus bertindak sebagai pencatat dan bertugas menuliskan ide atau gagasan yang muncul dari pikiran setiap siswa. Dalam hal ini, tidak perlu ada kekhawatiran terhadap persoalan tata bahasa, ejaan, bahkan kebenaran penjelasan yang dinyatakan oleh anggota kelompok. Hal yang penting adalah mendapatkan sebanyakbanyaknya penjelasan mengenai ide sentral yang telah ditentukan sebelumnya dalam waktu yang cepat. Apabila dikerjakan secara individual, pada prinsipnya seseorang mengerjakan hal yang sama dan juga harus mencatat ide-ide yang ditemukannya selama proses itu berlangsung.

\section{Prinsip Strategi Brainstorming}

Menurut (Darmadi, 1996:

43), ada dua prinsip penting dalam melaksanakan strategi brainstorming, yaitu:

1) Ide-ide yang dituangkan secara cepat tanpa memikirkan benar atau tidaknya, sesuai dengan topik atau tidak, penting atau tidak penting, dan sebagainya, dituliskan dalam bentuk daftar.

2) Adanya ide atau gagasan yang tidak berkaitan dengan topik dianggap sebagai sesuatu yang wajar karena memang belum dievaluasi. Daftar ide atau gagasan yang telah ditulis akan dipilih satu topik yang bisa mewakili keseluruhan ide dan kemudian akan dikembangkan menjadi sebuah tulisan.

4. Keuntungan dan Kelemahan Penggunaan Strategi Brainstorming 
Adapun keuntungan dari strategi brainstorming yaitu bahwa secara sadar atau tidak seorang penulis telah memulai proses berpikir. Rangkaian proses berpikir seperti ini akan membangkitkan energi intelektual yang dimiliki seseorang. Jika proses berpikir itu dilakukan secara berkesinambungan, rangkaian proses berpikir akan menghasilkan ide-ide yang lebih menarik dari pada ide-ide pada awalnya. Tanpa disadari penulis terkadang begitu saja mengeluarkan gagasannya dan ternyata gagasan tersebut adalah gagasan yang baik. Hal ini akan menjadi hal yang wajar dari seorang penulis dan kelanjutan proses dalam menuangkan ide-ide atau gagasan yang baik (Darmadi, 1996: 44).

Keuntungan penggunaan strategi brainstorming diungkapkan pula oleh Roestiyah (2008: 74), yaitu:

1) Anak-anak aktif berpikir untuk menyatakan pendapat.

2) Melatih siswa berpikir dengan cepat dan tersusun logis.

3) Merangsang siswa untuk selalu siap berpendapat yang berhubungan dengan masalah yang diberikan oleh guru.

4) Meningkatkan pertisipasi siswa dalam menerima pelajaran.

5) Siswa yang kurang aktif mendapat bantuan dari temannya yang pandai atau dari guru.

6) Terjadi persaingan yang sehat.

7) Anak merasa bebas dan gembira.

8) Suasana demokrasi dan disiplin dapat ditumbuhkan.

Menurut Roestiyah (2008: 75), strategi brainstorming juga memiliki kelemahan yang perlu diatasi, yaitu:

1) Guru kurang memberi waktu yang cukup kepada siswa untuk berpikir dengan baik.
2) Anak yang kurang selalu ketinggalan.

3) Kadang-kadang pembicaraan hanya dimonopoli oleh anak yang pandai.

4) Guru hanya menampung pendapat dan tidak merumuskan kesimpulan.

5) Siswa tidak segera tahu apakah pendapatnya itu benar atau salah.

6) Tidak menjamin hasil pemecahan masalah.

7) Masalah bisa berkembang ke arah yang tidak diharapkan.

Namun demikian, strategi ini sering menguntungkan, supaya berhasil sebaiknya digabung dengan strategi yang lain.

\section{Langkah-langkah dalam \\ Penerapan Strategi \\ Pembelajaran Brainstorming}

Menurut Nurudin, (2007: 95-

101) langkah-langkah dalam penerapan strategi brainstorming, yaitu:

\section{a) Listing}

Listing (mendaftar) adalah teknik brainstorming yang mampu mengarahkan untuk berpikir tentang sebuah topik dan secara cepat membuat daftar kata-kata apa yang muncul dalam pikiran, meliputi:

(a) tulis topik umum di bagian atas kertas;

(b) buat daftar setiap gagasan yang ada dalam pikiran Anda tentang topik yang dipilih itu. Buatlah gagasan secara mengalir. Tulis apa adanya. Coba berhenti pada topik yang Anda anggap umum;

(c) gunakan kata, gabungan kata atau kalimat;

(d) kelompokkan menjadi tiga bagian dengan pertimbangan dalam satu kelompok berisi topik yang berkaitan satu sama lain. Cari kata atau kumpulan kata mana yang 
kira-kira bisa menjadi topik yang paling luas dan bisa merangkum kata-kata dikelompok masingmasing.

\section{b) Freewriting}

Freewriting adalah menulis bebas sebuah topik. Tujuannya untuk mencari fokus yang lebih spesifik dan dapat menggeneralisasi sebanyak mungkin gagasan. Adapun langkahlangkahnya meliputi:

(a) tulis topik pada bagian atas kertas;

(b) tulis sebanyak mungkin yang Anda dapat tentang topik itu sampai keluar dari gagasan atau sampai habis gagasan tentang topik itu dalam otak Anda. Jangan lupa masukkan pula contoh, fakta, data, detail, yang saat itu muncul dalam pikiran Anda saat menulis;

(c) ambil gagasan utama untuk menulis bebas lagi.

\section{METODE PENELITIAN}

Jenis penelitianini menggunakan penelitian eksprimen semu, desain "pretest-postes control group design", dengan rancangan pretest dan postestpada kelas kontrol dan kelas eksperimen.

Dalam penelitian ini terdapat dua variabel yang diamati, yaitu variabel $\mathrm{X}$ dan variabel $\mathrm{Y}$. Variabel $X$ adalah pembelajaran strategi braistorningsebagai variabel bebas (independen), sedangkan variabel $\mathrm{Y}$ adalah kemampuan siswa menulis paragraf argumentasisebagai variabel terikat (dependen).

Populasi penelitian ini adalah seluruh siswa kelas XISMA Negeri 1Bontonompo Kabupaten Gowa yang berjumlah 123 orang siswa.Adapun kelas yang terpilih menjadi sampel, yaitu kelas $\mathrm{VIII}_{\mathrm{A}}$ sebagai kelas eksperimen dan kelas $\mathrm{VIII}_{\mathrm{B}}$ sebagai kelas kontrol.
Instrumen dalam penelitian ini terdiri atas dua, yaitu instrumen yang berkaitan dengan pembelajaran menulis paragraf argumentasidengan menerapkan strategi brainstormingdan instrumen yang kedua adalah tugas menulis paragraf argumentasiberupa pedoman paragraf argumentasi. Pedoman tersebut digunakan pada tes awal dan tes akhir baik pada kelas kontrol maupun pada kelas eksperimen.

Teknik pengumpulan datadalam penelitian ini adalah teknik tes yang digunakan untuk mengukur kemampuan siswa dalam aspek kognitif, atau tingkat penguasaan materi pembelajaran.Tes yang diberikan pada saat pretest dan postestadalah tes menulis par -...r argumentasiuntuk mengetahui st mana pemahaman siswa mens...... paragraf argumentasi. Observasi dilakukan terhadap keadaan siswa ketika sedang mengikuti pembelajaran menulis paragraf argumentasidengan menerapkan pembelajaran ceramah dan tanya jawab di kelas kontrol. Tujuan observasi ini dilakukan yaitu untuk mengetahui proses pembelajaran dan akibat yang timbul setelah pembelajaran tersebut.

Analis data dilakukan setelah semua data terkumpul. Adapun langkah-langkah dalam analisis data sebagai berikut.

1. Menganalisis hasil pretest dan postest hasil menulis paragraf argumentasisiswa.

2. Mendeskripsikan hasil pretest dan postest hasil menulis paragraf argumentasisiswa.

3. Menentukan skor pretest dan postest, kemudian menentukan nilai dengan rumus;

Nilai $=\frac{\text { Skoryangdiperoleh }}{\text { Skormaksimum }} X 100$

4. Melakukan uji normalitas nilai pretest dan postest, dan indeks 
gain menguji normalitas nilai pretest dan postest, dengan uji Kolmogorov Smirnov berkehendak untuk menguji hipotesis bahwa tidak ada bedanya antara dua buahdistribusi atau untuk menentukan apakah distribusi dua sampel mempunyai bentuk yang serupa (Nasir, 1988: 486 ). Pengelolahan data statistik dilakukan dengan menggunakan bantuan softwareSPSS versi 20.0forwindows.

Pasangan hipotesis nol dan hipotesis tandingannya adalah:

Ho : Sampel berasal dari populasi yang berdistribusi normal

Hi : Uji statistik yang akan digunakan adalah uji Kolmogorov Smirnov dengan mengambil taraf signifikasi (a) sebesar 0,05. Kriteria pengujiannya adalah $\mathrm{Ho}$ diterima jika nilai signifikasi > 0,05 dan tolak Ho jika nilai signifikasi < 0,05 ( Priyatno, 2009: 40)

5. Uji kesamaan dua rata-rata nilai pretest,postest, dan indeks gain pengujiannya hipotesis dilakukan Tabel 3.1 Penilaian Tingkat Kemampuan MenulisParagraf Argumentasi

\begin{tabular}{cc}
\hline Skor perolehan & Kategori \\
\hline $90-100$ & Sangat Tinggi (ST) \\
\hline $80-89$ & Tinggi (T) \\
\hline $65-79$ & Sedang (S) \\
\hline $55-64$ & Rendah (R) \\
\hline$<54$ & Sangat rendah (SR) \\
\hline
\end{tabular}

IV. Hasil Penelitian Dan Pembahasan

A. Hasil Penelitian

1. Hasil Analisis Penerapan Strategi Brainstormingdalam Pembelajaran Menulis Paragraf Argumentasi

a) Analisis Data Pretest Kelas Eksperimen

Tabel 4Tingkat Kemampuan Menulis Paragraf Argumentasi Nilai Pretest Kelas Eksperimen



dengan uji statistik nonparametik yaitu uji Mann Wheatney. Pengelolahan data statistik dilakukan dengan menggunakan bantuan softwareSPSS versi 20.0 for windows. Secara defaultSPSS sudah menggunakan tingkat signifikansi 0,05 (Priyatno, 2009:76).

Taraf signifikansi (a) sebesar 0,05 . Kriteria pengujiannya yaitu jika nilai signifikansi (2-tailed) $>$ (b) $=0,05$ maka Ho diterima atau jika nilai signifikansi (2-tailed $)<0,05$ maka Ho ditolak.

Data yang diperoleh dikumpulkan kemudian dianalisis, untuk analisis data kuantitatif digunakan teknik analisis deskriptif dimaksudkan untuk mendiskripsikan skor rata-rata, skor tertinggi, skor terendah, rentang skor, standar deviasi, dan tabel frekuensi serta persentase.

Kriteria yang digunakan untuk kategori ini adalah berdasarkan teknik kategorisasi standar yang menurut Nana Sudjana (Wardanah: 2008) adalah sebagai berikut.

Berdasarkan hasil analisis data pretest kelas eksperimen dari 30 siswa diperoleh gambaran, yaitu tidak ada siswa yang memeroleh nilai 100 sebagai nilai maksimal. Nilai tertinggi, yaitu 87 diperoleh 1 orang siswa dan nilai terendah 46 diperoleh 6 orang siswa. 


\begin{tabular}{ccccc}
\hline & & & $\%$ & Rata \\
\hline $90-100$ & Sangat & 0 & $0 \%$ & - \\
$80-89$ & Tinggi & 2 & $6,7 \%$ & - \\
$65-79$ & Tinggi & 10 & $33,3 \%$ & - \\
$55-64$ & Sedang & 12 & $40 \%$ & 60,93 \\
$<54$ & Rendah & 6 & $20 \%$ & - \\
& Sangat & & & \\
\hline & Rendah & & & \\
\hline \multicolumn{2}{c}{ Total } & 30 & $100 \%$ & - \\
\hline
\end{tabular}

Tabel 3.2 menggambarkan bahwa skor pretest pada kelas eksperimen berada pada kategori sangat rendah diperoleh 6 orang siswa (20\%), kategori rendah diperoleh 12 orang siswa $(40 \%)$, kategori sedang diperoleh 10 orang siswa $(33,3 \%)$, kategori tinggi diperoleh 2 orang siswa $(6,7 \%)$, dan tidak ada siswa yang memeroleh nilai sangat tinggi $(0 \%)$.

Setelah diperoleh nilai ratarata pretest siswa pada kelas eksperimen dalam menulis paragraf argumentasi dapat disimpulkan bahwa kemampuan siswa kelas eksperimen sebelum diberikan perlakuan termasuk dalam kategori rendah, terlihat pada Tabel tersebut yang menunjukkan bahwa nilai 60,93 berada pada interval 55-64 (kategori rendah).

b) Analisis Data Postest Kelas Eksperimen

Berdasarkan hasil analisis data postest kelas eksperimen dari 30 siswa diperoleh gambaran, yaitu tidak ada siswa yang memeroleh nilai 100 sebagai nilai maksimal. Nilai tertinggi, yaitu 93 diperoleh 3 orang siswa dan nilai terendah 60 diperoleh 2 orang siswa.

Tabel 3.3 Tingkat Kemampuan Menulis Paragraf Argumentasi Nilai Postest Kelas Eksperimen

\begin{tabular}{ccccc}
\hline Interval & Kategori & Frekuensi & Persentase \% & Rata-Rata \\
\hline $90-100$ & Sangat Tinggi & 3 & $10 \%$ & - \\
$80-89$ & Tinggi & 15 & $50 \%$ & - \\
$65-79$ & Sedang & 10 & $33,3 \%$ & 78,87 \\
$55-64$ & Rendah & 2 & $6,7 \%$ & - \\
$<54$ & Sangat Rendah & 0 & $0 \%$ & - \\
\hline \multicolumn{7}{c}{ Total } & 30 & $100 \%$ & - \\
\hline
\end{tabular}

Tabel 3.3 menggambarkan bahwa skor postest pada kelas eksperimen tidak terdapat siswa $(0 \%)$ berada pada kategori sangat rendah, kategori rendah diperoleh 2 orang siswa $(6,7 \%)$, kategori sedang diperoleh 10 orang siswa $(33,3 \%)$, kategori tinggi diperoleh 15 orang siswa (50\%), dan kategori sangat tinggi diperoleh 3 orang siswa (10\%).

Setelah diperoleh nilai ratarata postest siswa pada kelas eksperimen dalam menulis paragraf argumentasi dapat disimpulkan bahwa kemampuan siswa kelas eksperimen setelah diberikan perlakuan termasuk dalam kategori sedang, terlihat pada Tabel tersebut yang menunjukkan bahwa nilai rata-rata 78,87 berada pada interval 65-79 (kategori sedang).
2. Hasil
Analisis
Penerapan
Konvensionaldalam Pembelajaran Menulis Paragraf Argumentasi 
a) Analisis Data Pretest Kelas Kontrol

Berdasarkan hasil analisis data pretest kelas kontrol dari 30 siswa diperoleh gambaran, yaitu tidak ada siswa yang memeroleh nilai 100

Tabel 3.4Tingkat Kemampuan Menulis Paragraf Argumentasi Nilai Pretest Kelas Kontrol

\begin{tabular}{ccccc}
\hline Interval & Kategori & Frekuensi & $\begin{array}{c}\text { Persentase } \\
\%\end{array}$ & $\begin{array}{c}\text { Rata- } \\
\text { Rata }\end{array}$ \\
\hline $90-100$ & Sangat & 0 & $0 \%$ & - \\
$80-89$ & Tinggi & 6 & $20 \%$ & - \\
$65-79$ & Tinggi & 10 & $33,3 \%$ & - \\
$55-64$ & Sedang & 5 & $16,7 \%$ & 64,77 \\
$<54$ & Rendah & 9 & $30 \%$ & - \\
& Sangat & & & \\
\hline & Rendah & & & - \\
\hline \multicolumn{2}{c}{ Total } & 30 & $100 \%$ & -
\end{tabular}

Tabel 3.4 menggambarkan bahwa skor pretest pada kelas kontrol berada pada kategori sangat rendah diperoleh 9 orang siswa $(30 \%)$, kategori rendah diperoleh 5 orang siswa $(16,7 \%)$, kategori sedang diperoleh 10 orang siswa $(33,3 \%)$, kategori tinggi diperoleh 6 orang siswa $(20 \%)$, dan tidak ada siswa yang memeroleh nilai sangat tinggi $(0 \%)$.

Setelah diperoleh nilai ratarata pretest siswa pada kelas kontrol dalam menulis paragraf argumentasi dapat disimpulkan bahwa kemampuan siswa kelas kontrol sebelum diberikan

Tabel 3.5 Tingkat Kemampuan Menulis Paragraf Argumentasi Nilai Postest Kelas Kontrol

\begin{tabular}{ccccc}
\hline Interval & Kategori & Frekuensi & $\begin{array}{c}\text { Persentase } \\
\%\end{array}$ & $\begin{array}{c}\text { Rata- } \\
\text { Rata }\end{array}$ \\
\hline $90-100$ & Sangat & 0 & $0 \%$ & - \\
$80-89$ & Tinggi & 12 & $40 \%$ & - \\
$65-79$ & Tinggi & 13 & $43,3 \%$ & 73,80 \\
$55-64$ & Sedang & 5 & $16,7 \%$ & - \\
$<54$ & Rendah & 0 & $0 \%$ & - \\
& Sangat & & & \\
& Rendah & & & \\
\hline Total & & 30 & $100 \%$ & - \\
\hline
\end{tabular}

Tabel 3.5 menggambarkan bahwa skor postest pada kelas kontrol sebagai nilai maksimal. Nilai tertinggi, yaitu 87 diperoleh 3 orang siswa dan nilai terendah 46 diperoleh 5 orang siswa. perlakuan termasuk dalam kategori rendah, terlihat pada Tabel tersebut yang menunjukkan bahwa nilai 64,77 berada pada interval 55-64 (kategori rendah).

b) Analisis Data Postest Kelas Kontrol

Berdasarkan hasil analisis data postest kelas kontrol dari 30 siswa diperoleh gambaran, yaitu tidak ada siswa yang memeroleh nilai 100 sebagai nilai maksimal. Nilai tertinggi, yaitu 87 diperoleh 5 orang siswa dan nilai terendah 60 diperoleh 5 orang siswa. 
diperoleh 5 orang siswa $(16,7 \%)$, kategori sedang diperoleh 13 orang siswa $(43,3 \%)$, kategori tinggi diperoleh 12 orang siswa $(40 \%)$, dan tidak terdapat siswa berada pada kategori sangat tinggi (0\%).

Setelah diperoleh nilai ratarata postest siswa pada kelas kontrol dalam menulis paragraf argumentasi dapat disimpulkan bahwa kemampuan siswa kelas kontrol setelah diberikan

Tabel 3.6 Uji Normalitas Kolmogorov-Smirnov untuk Data Pretest Kelas Eksperimen

\begin{tabular}{lcccccc}
\hline & \multicolumn{3}{c}{ Tests of Normality } & \multicolumn{3}{c}{ Shapiro-Wilk } \\
\hline & \multicolumn{3}{c}{ Kolmogorov-Smirnov ${ }^{\mathrm{a}}$} & \multicolumn{3}{c}{ Stig. } \\
\cline { 2 - 7 } & Statistic & Df & Sig. & Stati & df & Sig. \\
\hline $\begin{array}{l}\text { Nilai } \\
\text { Eksperimen }\end{array}$ &, 133 & 30 & $\mathbf{, 1 8 3}$ &, 933 & 30 &, 058 \\
\hline
\end{tabular}

Taraf signifikansi pretest kelas eksperimen yang diberi simbol $p=0,183$ ini berarti signifikansi $p>\alpha=0,05$ berarti data yang diambil mengikuti distribusi normal. Eksperimen

Tabel 3.7 Uji Normalitas Kolmogorov-Smirnov untuk Data Postest Kelas

\begin{tabular}{lcccccc}
\hline & \multicolumn{4}{c}{ Tests of Normality } & & \\
\hline & \multicolumn{3}{c}{ Kolmogorov-Smirnov } & \multicolumn{3}{c}{ Shapiro-Wilk } \\
\cline { 2 - 8 } & Statistic & Df & Sig. & Statisti & df & Sig. \\
\hline $\begin{array}{l}\text { Nilai } \\
\text { Eksperimen }\end{array}$ &, 151 & 30 & $\mathbf{0 8 0}$ &, 932 & 30 &, 056 \\
\hline
\end{tabular}

Taraf signifikansi postest kelas eksperimen yang diberi simbol $p=0,080$ ini berarti signifikansi $p>\alpha=0,05$ berarti data yang diambil mengikuti distribusi normal.

Tabel 3.7 Uji Normalitas Kolmogorov-Smirnov untuk Data Pretest Kelas Kontrol

\section{Tests of Normality}

\begin{tabular}{lcccccc}
\hline & \multicolumn{4}{c}{ Kolmogorov-Smirnov ${ }^{\mathrm{a}}$} & \multicolumn{3}{c}{ Shapiro-Wilk } \\
\cline { 2 - 7 } & Statistic & df & Sig. & $\begin{array}{c}\text { Statisti } \\
\text { c }\end{array}$ & df & Sig. \\
\hline Nilai Kontrol &, 116 & 30 & $\mathbf{, 2 0 0}^{*}$ &, 934 & 30 &, 063 \\
\hline
\end{tabular}

Taraf signifikansi pretest kelas kontrol yang diberi simbol $p=0,200$ ini berarti signifikansi $p>\alpha=0,05$ berarti data yang diambil mengikuti distribusi normal. 
Tabel 3.8 Uji Normalitas Kolmogorov-Smirnov untuk Data Postest Kelas Kontrol

\begin{tabular}{lccccccc}
\hline & \multicolumn{3}{c}{ Tests of Normality } & & \\
\hline & \multicolumn{4}{c}{ Kolmogorov-Smirnov ${ }^{\text {a }}$} & \multicolumn{3}{c}{ Shapiro-Wilk } \\
\cline { 2 - 8 } & Statistic & df & Sig. & $\begin{array}{c}\text { Statisti } \\
\text { c }\end{array}$ & df & Sig. \\
\hline Nilai Kontrol &, 155 & 30 & $\mathbf{, 0 6 2}$ &, 909 & 30 &, 014 \\
\hline
\end{tabular}

Taraf signifikansi postest kelas kontrol yang diberi simbol $p=0,062$ ini berarti signifikansi $p>\alpha=0,05$ berarti data yang diambil mengikuti distribusi normal. a. Uji Homogenitas Kontrol

Tabel 3.9 Uji Homogenitas untuk Data Postest Kelas Eksperimen dan Kelas

\begin{tabular}{lllrrr}
\hline \multicolumn{7}{c}{ Test of Homogeneity of Variance } \\
\hline & \multicolumn{7}{c}{ Levene Statistic } & df1 & df2 & \multicolumn{1}{c}{ Sig. } \\
\hline $\mathrm{N}$ & Based on Mean &, 003 & 1 & 58 & $\mathbf{9 6 0}$ \\
\cline { 2 - 6 } $\mathrm{i}$ & Based on Median &, 009 & 1 & 58 &, 925 \\
\cline { 2 - 6 } $\mathrm{l}$ & $\begin{array}{l}\text { Based on Median and } \\
\text { with adjusted df }\end{array}$ &, 009 & 1 & 57,849 &, 925 \\
\cline { 2 - 6 } $\mathrm{i}$ & $\begin{array}{l}\text { Based on trimmed } \\
\text { mean }\end{array}$ & & & & \\
\hline
\end{tabular}

Oleh karena taraf sig $=0,960$, ini berarti nilai sig pada kelas eksperimen dan kelas kontrol lebih besar daripada $\alpha=0,05, \mathrm{H}_{0}$ diterima yang berarti data yang diambil cenderung sama atau homogen.

4. Analisis Inferensial Keefektivan Strategi Brainstorming.dalam Pembelajaran Menulis Paragraf Argumentasi
Penyajian analisis inferensial berikut ini adalah hasil uji t-test jenis Independent Samples Test untuk mengukur keefektivan strategi brainstorming.. Hasil analisis statistik Independent Samples Test diperoleh hasil sebagai berikut.

Independent Samples Test

\begin{tabular}{|c|c|c|c|c|c|c|c|c|}
\hline & & \multicolumn{2}{|c|}{$\begin{array}{l}\text { Levene's Test } \\
\text { for Equality } \\
\text { of Variances }\end{array}$} & \multicolumn{5}{|c|}{ t-test for Equality of Means } \\
\hline & & $\mathrm{F}$ & Sig. & $\mathrm{T}$ & $\mathrm{df}$ & $\begin{array}{l}\text { Sig. (2- } \\
\text { tailed) }\end{array}$ & $\begin{array}{c}\text { Mean } \\
\text { Difference }\end{array}$ & $\begin{array}{l}\text { Std. Error } \\
\text { Difference }\end{array}$ \\
\hline $\begin{array}{l}\text { Nil } \\
\text { ai }\end{array}$ & $\begin{array}{l}\text { Equal } \\
\text { variances } \\
\text { assumed }\end{array}$ & ,003 & 960 & $\begin{array}{l}2,1 \\
87\end{array}$ & 58 & ,033 & 5,067 & 2,317 \\
\hline
\end{tabular}




\begin{tabular}{lccccc}
\hline Equal & 2,1 & 58,0 &, 033 & 5,067 & 2,317 \\
variances not & 87 & 00 & & & \\
assumed & & & & & \\
\hline Tabel 3.10 Hasil Statistik Uji t-test & & & &
\end{tabular}

Tabel 3.10 Hasil Statistik Uji t-test

Berdasarkan hasil analisis data, diperoleh nilai thitung sebesar 2,187 pada taraf signifikan $p=0,033$, karena $p<$ $\alpha=0,05$. Jadi, kesimpulan yang dapat diperoleh adalah hipotesis nol $\left(\mathrm{H}_{0}\right)$ ditolak dan hipotesis satu $\left(\mathrm{H}_{1}\right)$ diterima. Hasil analisis tersebut menunjukkan bahwa ada perbedaan yang signifikan antara nilai menulis eksposisi pada kelas eksperimen dengan kelas kontrol. Hal ini berarti penerapan strategibrainstorming diterapkan pada pembelajaran menulis Paragraf Argumentasi siswa kelas XI SMA Negeri 1Bontonompo Kabupaten Gowa

B. Pembahasan

1. Kemampuan Menulis Paragraf Argumentasi melalui Penerapan Strategi Brainstorming

Kemampuan siswa dalam menulis paragrafargumentasi melalui strategi brainstorming pada kelas eksperimen dapat dilihat pada pemerolehan nilai rata-rata siswa setelah diadakan perlakuan (tindakan) mencapai 78,87 , dari hasil tes awal (pretest) yang hanya mencapai nilai rata-rata 60,93. Selain itu, setelah diadakan perlakuan, perolehan nilai tertinggi yaitu mencapai 93 yang diperoleh 3 orang siswa dengan persentase $(10 \%)$, sedangkan nilai terendah yaitu 60 yang hanya diperoleh 2 orang siswa dengan persentase $(6,7 \%)$. Hal tersebut menunjukkan adanya peningkatan dari hasil pretest ke postest.

Berdasarkan uraian pada hasil menulis paragraf argumentasi setelah diadakan strategi brainstormingmenunjukkan bahwa teknik tersebut efektif diterapakan dalam pembelajaran menulis paragraf argumentasi. Hal tersebut sejalan dengan pembelajaran yang diterapkan dalam strategi brainstormingmenurut Cullen (dalam Marina, 2005:30), brainstorming sangat bermanfaat bagi siswa dalam membantu mengembangkan pengetahuannya di dalam kelas dalam proses pembelajaran. Strategi ini lebih dinamis dan menyenangkan digunakan karena setiap siswa diberikan kesempatan untuk berbicara dengan cara menuliskan ide, gagasan, pendapat, dan komentarnya terhadap suatu hal tertentu dalam bentuk menulis secara bebas apa yang terdapat dalam pikirannya selain itu, keuntungan penggunaan strategi brainstorming diungkapkan pula oleh Roestiyah (2008: 74), yaitu: (1) anakanak aktif berpikir untuk menyatakan pendapat, (2) melatih siswa berpikir dengan cepat dan tersusun logis, (4) merangsang siswa untuk selalu siap berpendapat yang berhubungan dengan masalah yang diberikan oleh guru, (4) meningkatkan pertisipasi siswa dalam menerima pelajaran, (5) siswa yang kurang aktif mendapat bantuan dari temannya yang pandai atau dari guru, (6) terjadi persaingan yang sehat, (7) anak merasa bebas dan gembira dan (8) suasana demokrasi dan disiplin dapat ditumbuhkan.

2. Kemampuan Menulis Paragraf Argumentasi melalui Penerapan Pembelajaran Konvensional

Pembelajaran konvensional merupakan suatu pembelajaran yang masih sangat banyak diterapkan oleh 
guru-guru di sekolah yang ditandai dengan ceramah, tanya jawab, dan penugasan. Pembelajaran ini cenderung pada belajar hafalan, siswa dituntut untuk menghafal materi kemudian dilakukan tanya jawab. Hasil penelitian yang dilakukan pada kelas kontrol khususnya pada kelas $\mathrm{VIII}_{\mathrm{B}}$ menunjukkan bahwa nilai rata-rata siswa saat dilakukan pretest yaitu 64,77 , nilai tertinggi 87 diperoleh 3 orang siswa dengan persentase (10\%) dan nilai terendah diperoleh 5 orang siswa dengan persentase $(16,7 \%)$. Setelah diadakan postest dalam pembelajaran menulis paragraf argumentasi, nilai rata-rata yaitu mencapai 73,80 , nilai tertinggi 87 diperoleh 5 orang siswa dengan persentase $(16,7 \%)$ dan nilai terendah 60 juga diperoleh 5 orang siswa dengan persentase $(16,7 \%)$. Sesuai dengan hasil pencapaian KKM yaitu siswa yang memeroleh nilai $70 \mathrm{ke}$ atas sebanyak 20 orang siswa dengan persentase $(66,7 \%)$ dan siswa yang memeroleh nilai 70 ke bawah sebanyak 10 orang siswa dengan persentase $(33,3 \%)$. Dengan demikian, dapat dikatakan bahwa tingkat pembelajaran menulis paragraf argumentasi melalui pembelajaran konvensional pada kelas kontrol belum memadai karena apabila dikonfirmasikan dengan nilai KKM sekolah pada mata pelajaran bahasa Indonesia, yaitu siswa dinyatakan mampu apabila jumlah siswa mencapai $85 \%$ yang memeroleh nilai 70 ke atas.

Berdasarkan temuan pada kelas kontrol dengan menarapkan pembelajaran konvensional, menunjukkan tingkat pembelajaran menulis paragraf argumentasi belum memadai. Hal tersebut terlihat pada proses yang diterapkan pada kelas kontrol sepenuhnya masih ada pada kendali guru. Siswa kurang diberikan kesempatan dalam berkreasi atau menemukan sendiri dan pengalaman belajar juga masih sangat terbatas.

3. Keefektivan

Strategi

Brainstormingdalam Pembelajaran Menulis Paragraf Argumentasi

Berdasarkan uraian hasil pembelajaran pada kelas kontrol dan kelas eksperimen, tampak perbedaan yang signifikan pada nilai yang diperoleh siswa. Hal ini mengindikasikan bahwa strategi brainstormingefektif diterapkan dalam pembelajaran menulis paragraf argumentasi. Hal ini didukung oleh analisis statistik yang menyatakan bahwa $t_{\text {hitung }}>t_{\text {tabel }}$ atau $t_{\text {hitung }}$ sebesar 2,187 dibandingkan dengan $t_{\text {tabel }}$ sebesar 2,002. Dengan demikian, hasil yang diperoleh adalah hipotesis diterima, sehingga dapat dikatakan bahwa strategi brainstormingefektif diterapkan dalam pembelajaran menulis paragraf argumentasi pada siswa kelas XI SMA Negeri 1 Bontonompo Kabupaten Gowa.

\section{PENUTUP}

A. Simpulan

Berdasarkan hasil penelitian pada pelaksanaan pembelajaran menulis paragraf argumentasi melalui teknik clustering pada siswa kelas XI SMA Negeri 1 Bontonompo Kabupaten Gowa, dapat dipaparkan simpulan hasil penelitian sebagai berikut.

Terdapat perbedaan yang signifikan antara kefektivan siswa menulis paragraf argumentasi dengan menerapkan strategi brainstormingdan yang menerapkan pembelajaran konvensional. Hal ini tampak pada nilai rata-rata pada kelas kontrol yaitu 73,80, sedangkan pada kelas eksperimen mencapai 78,87. Selain itu, perbedaan tampak pada nilai $p$ value $<0,05$ atau $t_{\text {hitung }}$ sebesar 2,187 dibandingkan dengan $t_{\text {tabel }}$ 
sebesar 2,002 dengan taraf signifikan 0,033. Hal ini berarti $\mathrm{H}_{0}$ ditolak dan $\mathrm{H}_{1}$ diterima. Jadi dapat dikatakan bahwa strategi brainstormingefektif diterapkan dalam pembelajaran menulis paragraf argumentasi siswa kelas XI SMA Negeri 1 Bontonompo Kabupaten Gowa.

\section{B. Saran}

Berdasarkan simpulan hasil temuan pada penelitian ini, penulis memberikan saran sebagai berikut.

1. Diharapkan guru bahasa Indonesia lebih kreatif dalam proses pembelajaran khususnya dalam materi menulis, agar siswa merasa lebih termotivasi dalam mengikuti pembelajaran.

2. Diharapkan guru bahasa Indonesia untuk selalu menerapkan strategi brainstormingdalam pembelajaran bahasa Indonesia dan menyesuaikan materi yang disajikan.

3. Bagi peneliti lanjut untuk lebih mengembangkan penelitian ini agar lebih optimal dalam menerapkan strategi brainstormingdalam pembelajaran menulis paragraf argumentasi.

\section{DAFTAR PUSTAKA}

Darmadi. 1996. Meningkatkan Kemampuan Menulis. Yogyakarta: Andi Offset

Enre, Fachruddin Ambo. 1994. Dasardasar Keterampilan Menulis. Ujung Pandang: IKIP UJungpandang.

Hernowo. 2004. Langkah Mudah Membuat Buku yang Menggugah. Bandung: MLC.
Ismayani. 2007. Pembinaan Kemampuan Menulis Bahasa Indonesia. Jakarta : Erlangga.

Keraf, Gorys. 2007. Argumentasi dan Narasi. Jakarta: Gramedia Pustaka Utama.

Margono, S. 2007. Metodologi Research. Yogyakarta : FP UGM.

Masyita. 2008. Meningkatkan Kemampuan Menulis Paragraf Argumentasi dengan Menggunakan Metode Brainstorming di SMA Negeri 9 Makassar. Skripsi. Tidak diterbitkan. Makassar : Universitas Negeri Makassar.

Marzuki. 1974. MetodologiRiset. Yogyakarta : FEUII.

Nurudin. 2007. Dasar-dasar Penulisan. Malang: Universitas Negeri Malang.

Rahim, Abd Rahman. 2009. Bina Bahasa. Makassar: UMM.

Pappas. $\quad 1994 . \quad$ Menulis

Bandung:Angkasa

Roestiyah. 2008. Strategi Belajar Mengajar. Jakarta: Rineka Cipta.

Subagio. 2002. MetodePenelitiandalamTeo ri danPraktek.Jakarta : Rineka.

Syafi'ie, Imam. 1998. Retorika dalam Menulis. Jakarta: Depdikbud.

Tarigan, Henry Guntur. 2008. Menulis Sebagai Suatu Keterampilan Berbahasa. Bandung: Angkasa.

Zaenal. 2007. Cermat Berbahasa

Indonesia. Jakarta: Akapres 